\title{
Interplay of encrusting coralline algae and sea urchins in maintaining alternative habitats
}

\author{
Fabio Bulleri*, Iacopo Bertocci, Fiorenza Micheli \\ Dipartimento di Scienze dell'Uomo e dell'Ambiente, Via A. Volta 6, 56126 Pisa, Italy
}

\begin{abstract}
In proximity of shelters, grazing by sea urchins plays a fundamental role in establishing and maintaining areas dominated by encrusting corallines. Much attention has been given to the effects of urchins on algal assemblages in shallow subtidal reefs, but few studies attempted to clarify the role played by encrusting coralline algae in this system. It has been shown that encrusting corallines are able to reduce settlement of potential competitors, suggesting that they do not rely on grazing by herbivores to prevent swamping by erect algal species. In shallow subtidal reefs of the Mediterranean Sea, the sea urchins Paracentrotus lividus and Arbacia lixula are the main herbivores, whose grazing commonly leads to a mosaic of areas dominated alternatively by encrusting corallines and turf-forming algae. This study aims to separate the effects of urchins and encrusting corallines on the re-colonisation of encrusting corallinedominated patches (barren habitat) by surrounding erect algal species (turf-forming algae). Different hypotheses were tested by means of multivariate and univariate analyses. The multivariate hypothesis was that the algal assemblage developing when encrusting corallines and urchins are simultaneously removed would be more similar to that establishing in stands of turf-forming algae, than that developing when none or only 1 of the 2 factors is manipulated. The univariate hypotheses tested were: (1) that there is a negative effect of sea urchins and encrusting corallines on the re-colonisation of barren areas by surrounding turf-forming algal species and (2) that the effects of encrusting corallines are weaker than those of urchins, but that they operate in the same direction. These hypotheses were tested by means of an orthogonal manipulation of urchins and encrusting corallines. At each of 3 study sites, 2 replicate barren patches were assigned to each of these treatments: (1) +corallines+urchins; (2) +corallines-urchins; (3) -corallines+urchins; (4) -corallines-urchins. The results suggest that the occurrence of areas dominated by encrusting corallines on shallow subtidal reefs in the northwest Mediterranean is not simply the result of grazing by sea urchins on turf-forming species. The removal of encrusting corallines also affected the abundance of dominant algal species and determined the development of an algal assemblage resembling those occurring within stands of algal turfs. The effects of the removal of urchins on turfforming species were generally positive, while those of encrusting corallines varied from negative (Padina pavonica) to positive (Acetabularia acetabulum and filamentous algae). Therefore, the role played by encrusting corallines in maintaining alternative habitats on shallow subtidal reefs should be taken into account, thus avoiding the overestimation of the effects of grazing by sea urchins.
\end{abstract}

KEY WORDS: Sea urchins $\cdot$ Encrusting corallines $\cdot$ Turf-forming algae $\cdot$ Alternative habitats $\cdot$ Orthogonal manipulation $\cdot$ Mediterranean Sea

\section{INTRODUCTION}

In marine habitats, the abundance and distribution of consumers, either predators or herbivores, is often re-

${ }^{*}$ Present address: Centre for Research on Ecological Impacts of Coastal Cities, Marine Laboratories A11, University of Sydney, NSW 2006, Australia.

Email: fbulleri@bio.usyd.edu.au lated to the availability of refuges (Menge 1978, Lively 1986, Andrew 1993, Benedetti-Cecchi \& Cinelli 1995, Williams et al. 2000). The reliance on shelters, exhibited by certain species, can be an adaptive response to predation or a strategy to avoid harsh physical conditions (Branch 1975, Nelson \& Vance 1979, Fletcher 1987, Chapman \& Underwood 1992). When consumers aggregate in refuges and forage in nearby areas, they can nearly eliminate their prey, creating bare haloes within 
major stands of the prey (Odgen et al. 1973, BenedettiCecchi \& Cinelli 1995, Underwood 1999, Williams et al. 2000), leading to the establishment of a patchy mosaic of species (Levings \& Garrity 1983).

In subtidal habitats, the effects of some species of sea urchins on macro-algae are constrained by the presence of crevices and/or boulders (Andrew 1993, Benedetti-Cecchi \& Cinelli 1995, Bulleri et al. 1999). In such cases, the large pressure of grazing in proximity to the refuges can result in the elimination of erect macro-algae, enabling encrusting algae, mainly corallines, to monopolise the space. The presence of refuges, by enhancing the persistence of sea urchins, would maintain patchiness, characterised by the dominance of space by encrusting corallines (barren habitat) or, alternatively, by stands of erect algal species (turf-forming algae).

The processes involved in producing and maintaining barren areas by sea urchins have received considerable attention (Lawrence 1975, Sousa et al. 1981, Hawkins \& Hartnoll 1983, Himmelmann et al. 1983, Scheibling 1986, Witman 1987, Johnson \& Mann 1988, Valentine \& Heck 1991, Andrew \& Underwood 1993, BenedettiCecchi \& Cinelli 1995, Leinaas \& Christie 1996, Benedetti-Cecchi et al. 1998, Bulleri et al. 1999). However, few studies (Breitburg 1984, Johnson \& Mann 1986, Camus 1994) have investigated the role played by encrusting corallines in the shifts between the assemblages dominated by erect algae and coralline barrens.

Some authors have reported that encrusting algae rely on the presence of herbivores to prevent overgrowth by erect forms (Kitting 1980, Paine 1980, Steneck 1982, 1986). Others (Bertness et al. 1983, Sebens 1983, Masaki et al. 1984, Johnson \& Mann 1986, Dethier 1994 and references therein) have shown that crusts were able to reduce settlement of potential competitors, suggesting that their persistence does not strictly depend on the control of erect species by grazers.

In barren areas, the intensity of grazing by sea urchins can be variable not just in space, but also through time. For instance, sea urchins can switch from an active foraging behaviour to passive feeding on drift algae (Vance \& Schmitt 1979, Cowen et al. 1982, Carpenter 1984, Johnson \& Mann 1988, Scheibling \& Hamm 1991, Sala \& Zabala 1996). Furthermore, the density of sea urchins can be reduced by commercial harvesting (Kempf 1962, Boudoresque 1987) or by the outbreak of parasite infections (Hagen 1995), providing the opportunity for surrounding erect algal forms to re-colonise space. As argued by Breitburg (1984), the return to an assemblage like the pre-grazed state is related to the ability of recolonising species to recruit onto, or to overgrow, encrusting corallines when grazing is reduced. Therefore, it is necessary for studies aiming to evaluate the effects of sea urchins in determining the structure and dynamics of shallow subtidal reefs to take into account the role played by encrusting corallines. The orthogonal manipulation of encrusting corallines and sea urchins is the only way to evaluate fully their relative effects. Johnson \& Mann (1986) and Camus (1994) provided some evidence for the negative effects of encrusting corallines on the recruitment of erect macro-algae. Because their studies were done in the absence (Johnson \& Mann 1986) and in the presence (Camus 1994) of grazers, the effects of the 2 factors were not separated and there has been no evaluation of their interaction. In fact, there appear to have been no experimental studies specifically designed to separate the effects of encrusting corallines from those of grazing by urchins.

The urchins Paracentrotus lividus and Arbacia lixula are the most important herbivores on shallow subtidal rocky reefs in the Mediterranean Sea. It has been shown that, at high densities, they can eliminate erect macro-algae, creating haloes dominated by encrusting corallines within surrounding stands of turf-forming algae (Regis 1978, Verlaque \& Nedelec 1983, Verlaque 1984, Fanelli et al. 1994, Benedetti-Cecchi et al. 1998, Bulleri et al. 1999).

The goal of this study was to evaluate the effects of sea urchins and encrusting corallines on the re-colonisation of barren patches by surrounding turf-forming algae. Different hypotheses were tested by multivariate and univariate analyses. The multivariate hypothesis was that the algal assemblage developing when encrusting corallines and urchins are simultaneously removed would be more similar to that occurring in stands of turf-forming algae, than that developing when none or only one of the 2 factors is manipulated. Univariate hypotheses tested were: (1) that there is a negative effect of sea urchins and encrusting corallines on the re-colonisation of barren areas by surrounding turf-forming algal species and (2) that the effects of encrusting corallines are weaker than those of urchins, but that they operate in the same direction (i.e. the effects of encrusting corallines are likely to be masked when sea urchins are present).

These hypotheses were tested by an experimental removal of urchins and encrusting corallines.

\section{MATERIALS AND METHODS}

Study site. This study was done at Calafuria, an exposed rocky shore on the northwest coast of Italy $\left(43^{\circ} 28^{\prime} \mathrm{N}, 10^{\circ} 20^{\prime} \mathrm{E}\right)$, between October 1999 and June 2000. Shallow subtidal reefs were characterised by extensive stands of turf-forming algae, alternating with areas dominated by encrusting corallines, generally of a few square metres in extent. The cover of encrusting corallines was nearly complete in areas 
lacking turfs, but large storms had occasionally led to the exposure of primary substratum (bare rock), possibly through heavy scouring by boulders.

The most common turf-forming algae were several filamentous forms (e.g. Ceramium sp., Polysiphonia spp., Sphacelaria spp.), the articulated coralline Corallina elongata Ellis and Solander, the foliose Padina pavonica L. Lamoroux, Acetabularia acetabulum (Linnaeus) P. C. Silva, Dyctiota dicothoma (Hudson) Lamoroux and Taonia atomaria (Woodw.) J. Agarth, and the coarsely branched Laurencia obtusa (Hudson) Lamoroux and Chondria sp. Algae were grouped in morphological groups (Littler \& Littler 1980). The sea urchins Paracentrotus lividus Lam. and Arbacia lixula L., and the limpet Patella caerulea L. were commonly found in barren patches, while they were absent within stands of turfforming algae. Sessile invertebrates were represented only by the barnacle Balanus perforatus Bruguiére and the sessile tubicolous gastropod Vermetus sp.

Experimental design. Three sites, of about $400 \mathrm{~m}^{2}$ and no less than $50 \mathrm{~m}$ apart, were randomly identified along the coast, at a depth of 2-3 $\mathrm{m}$. The spatial array of sites was dictated by previous investigations, which showed that the effects of urchins varied at the scale of tens of metres (Benedetti-Cecchi et al. 1998, Bulleri et al. 1999). At each site, 8 barren patches, of about $3 \mathrm{~m}^{2}$, were chosen on gently sloping rocky platforms and were randomly assigned to each of the following treatment, 2 replicates for each: (1) +corallines+urchins $(+\mathrm{C}+\mathrm{U})_{i}(2)+$ corallines-urchins $(+\mathrm{C}-\mathrm{U})$; (3) -corallines+urchins $(-\mathrm{C}+\mathrm{U})$; (4) - corallines-urchins (-C-U). Furthermore, at each site, 2 patches of similar extent were marked within the stands of turf-forming algae, as required for the multivariate hypotheses. In order to compare assemblages developing following the manipulation of encrusting corallines and sea urchins with assemblages of turfing algae of the same age, 4 quadrats were scraped to bare rock in each of these patches.

Urchins were removed by hand and experimental conditions were maintained by means of fortnightly visits. Adults (test diameter $>2.5 \mathrm{~cm}$ ) were counted in December 1999 and in February and June 2000, in three $50 \times 50 \mathrm{~cm}^{2}$ randomly allocated quadrats, in each patch. The abundance of urchins was not assessed in stands of turfing algae, since they were never seen in this type of habitat.

Four replicate $13 \times 13 \mathrm{~cm}^{2}$ quadrats were randomly located in each patch, avoiding a $30 \mathrm{~cm}$ wide margin to prevent the occurrence of edge effects. To find them in subsequent visits, the quadrats were marked at their corners by means of Epoxy putty (Veneziani S Subcoat). Encrusting corallines and turf-forming algae were eliminated, where necessary, using a hammer and chisel, paying attention not to alter the topography of the substratum through the production of cracks. Only bare rock was left where encrusting corallines were removed.

The quadrats were sampled after 8 mo, using a $10 \times$ $10 \mathrm{~cm}^{2}$ plastic frame, subdivided into 25 sub-quadrats. A score from 0 to $4 \%$ was given for each taxon in each sub-quadrat (Dethier et al. 1993, Benedetti-Cecchi et al. 1998). In order to avoid edge effects, due to the re-colonisation of cleared quadrats by encrusting corallines through vegetative growth, we sampled the inner $10 \times 10 \mathrm{~cm}^{2}$ of each replicate quadrat.

Statistical analyses. To test our predictions at the level of the whole assemblage, we used a 2-factor nonparametric MANOVA model (Anderson 2001), with the random factor Patch nested within the fixed factor Treatment. The treatment had 5 levels: $+\mathrm{C}+\mathrm{U},+\mathrm{C}-\mathrm{U}$, $-\mathrm{C}+\mathrm{U},-\mathrm{C}-\mathrm{U}$ and Turf. This test allows partitioning of variation directly among individual terms in a multifactorial ANOVA model, allowing tests for the effects of treatment and to evaluate the variability at the scale of the patch (Anderson 2001). Separate analyses were run for each of the 3 sites. A matrix of similarity was calculated using the Bray-Curtis similarity index (Bray \& Curtis 1957) on untransformed data, and non-metric multidimensional scaling (nMDS) was used to produce 2-dimensional representations of similarities among samples in the different treatments, separately for each site.

The response of algae and invertebrates to the manipulation of sea urchins and encrusting corallines was assessed using mixed model ANOVAs, including the following factors: Corallines (+/-; fixed), Urchins (+/-; fixed and orthogonal), Site (random and orthogonal) and Patch (random and nested within the triple interaction of the other factors).

The effectiveness of the manipulation of sea urchins, was evaluated using a 4-factor ANOVA, including: Time (random), Site (random and orthogonal), Treatment (fixed and orthogonal, with 4 levels, corresponding to the combinations of the factors Corallines and Urchins) and Patch (random and nested within the interaction Site $\times$ Treatment).

Homogeneity of variances was checked using Cochran's $C$-test and data were transformed to $\ln$ $(x+1)$, when necessary. SNK tests were used for a posteriori comparisons of the means, when appropriate (Underwood 1997).

\section{RESULTS}

\section{Maintenance of experimental conditions}

The abundance of urchins differed among treatments (Fig. 1), although there were some inconsisten- 


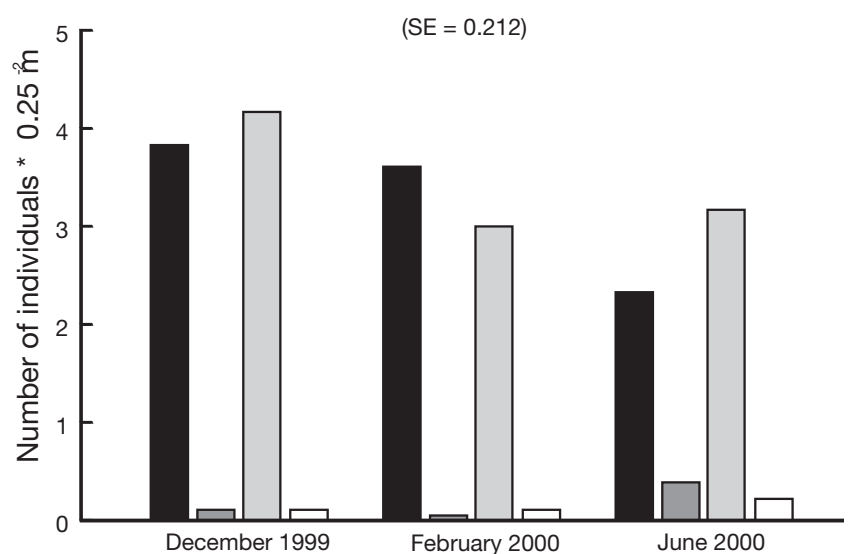

Fig. 1. Diagram of Time $\times$ Treatment interaction from the ANOVA of the abundance of sea urchins. The standard error for the comparison of the means is showed in brackets. Black

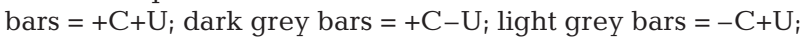
hollow bars $=-\mathrm{C}-\mathrm{U}$

cies through time (analysis on untransformed data, $C=0.111, \mathrm{p}>0.05$; Time $\times$ Treatment: $F_{6,12}=7.40^{* *}$, $\mathrm{MS}_{\text {Time }} \times$ Treatment $\left.=4.333\right)$. Nevertheless, there were more urchins in patches where they were left untouched than in patches where they had been removed, at every time of sampling (SNK tests). There were substantially more urchins in $-\mathrm{C}+\mathrm{U}$ than in $+\mathrm{C}+\mathrm{U}$ patches in June 2000, while there were no differences in December 1999 and February 2000 (SNK tests). The abundance of herbivores varied from patch to patch $\left(F_{12,24}=5.18^{* * *}, \mathrm{MS}_{\text {Patch (Site } \times \text { Treatment) }}=7.54\right)$.

\section{Multivariate analyses}

At Site 1, assemblages which developed when encrusting corallines were left in place, either in the presence or absence of sea urchins, grouped together and separated from those within turf-forming algae (Fig. 2, Table 1). Pair-wise comparisons in the non-parametric MANOVA indicated that turf-forming assemblages were significantly different from assemblages in experimental patches only when sea urchins and encrusting corallines were left untouched (Table 1). Assemblages where encrusting corallines had been removed were very variable within and between patches, irrespective of the manipulation of the herbivores (Fig. 2).

At Sites 2 and 3, a similar pattern emerged, but at both these sites, assemblages where encrusting corallines were present were significantly different from those in stands of turf-forming algae, irrespective of the presence or absence of sea urchins (Fig. 2, Table 1). Again, there was large variability within and
Site 1

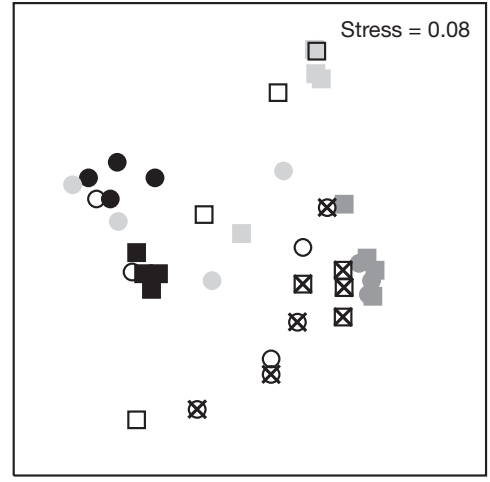

Site 2

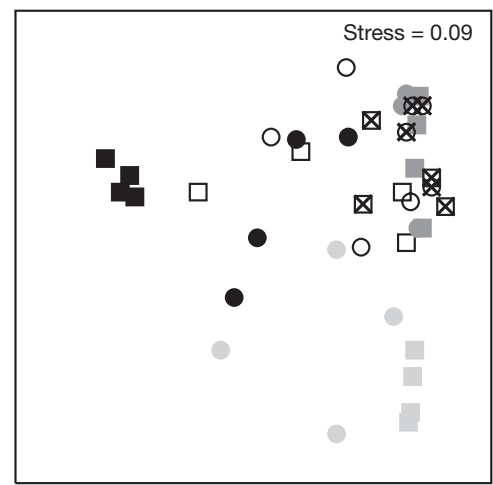

Site 3

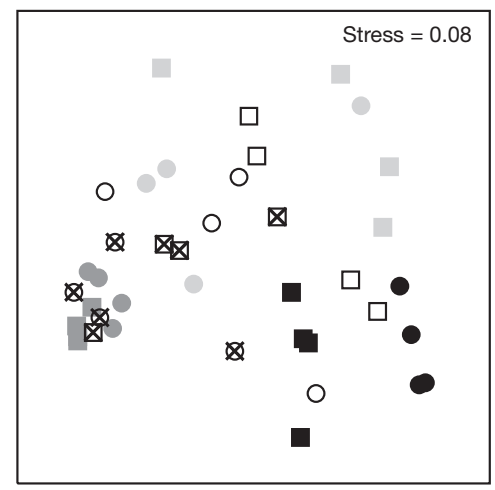

Fig. 2. nMDS ordination plots, comparing assemblages among treatments, separately for each site. Symbols: circle = Patch 1 ; square $=$ Patch 2 ; black $=$ Turf $;$ dark grey $=+C+\mathrm{U}_{i}$ crossed $=+\mathrm{C}-\mathrm{U}_{;}$light grey $=-\mathrm{C}+\mathrm{U}_{;}$hollow $=-\mathrm{C}-\mathrm{U}$

between patches for $-\mathrm{C}+\mathrm{U}$ and $-\mathrm{C}-\mathrm{U}$ treatments, each being indistinguishable from the other treatments.

Finally, there was great variability between patches at Sites 1 and 3, but not at Site 2 (Fig. 2, Table 1).

\section{Univariate analyses}

The most abundant algal taxa were filamentous algae, Acetabularia acetabulum and Padina pavonica. 
Table 1. Non-parametric MANOVA on Bray-Curtis similarities for assemblages in patches of different treatments

\begin{tabular}{|c|c|c|c|c|c|c|c|}
\hline \multirow[t]{2}{*}{ Source of variation } & \multirow{2}{*}{$\mathrm{df}$} & \multicolumn{2}{|r|}{ Site 1} & \multicolumn{2}{|c|}{ Site 2} & \multicolumn{2}{|c|}{ Site 3} \\
\hline & & MS & $F$ & MS & $F$ & MS & $F$ \\
\hline Treatment $=\operatorname{Tr}$ & 4 & 11032.126 & $2.90^{* * *}$ & 9691.591 & $4.13^{* * *}$ & 11454.582 & $2.08^{*}$ \\
\hline Patch (Tr) & 5 & 3799.062 & $1.93^{* *}$ & 2348.779 & 1.49 & 5494.928 & $3.17^{* * *}$ \\
\hline Residual & 30 & 1975.662 & 1572.374 & 1730.523 & & & \\
\hline Comparison & & Site 1 & & Site 2 & & Site 3 & \\
\hline Turf versus $-\mathrm{C}+\mathrm{U}$ & & 1.32 & & 2.37 & & 1.22 & \\
\hline Turf versus $-\mathrm{C}-\mathrm{U}$ & & 1.61 & & 1.79 & & 1.64 & \\
\hline Turf versus $+\mathrm{C}+\mathrm{U}$ & & $3.12^{*}$ & & $3.11^{* *}$ & & $2.61^{* *}$ & \\
\hline Turf versus $+\mathrm{C}-\mathrm{U}$ & & 2.33 & & $3.12^{*}$ & & $2.40^{*}$ & \\
\hline$-\mathrm{C}+\mathrm{U}$ versus $-\mathrm{C}-\mathrm{U}$ & & 0.55 & & 0.82 & & 0.67 & \\
\hline$-\mathrm{C}+\mathrm{U}$ versus $+\mathrm{C}+\mathrm{U}$ & & 1.43 & & 1.92 & & 0.72 & \\
\hline$-\mathrm{C}+\mathrm{U}$ versus $+\mathrm{C}-\mathrm{U}$ & & 1.16 & & 1.53 & & 0.81 & \\
\hline$-\mathrm{C}-\mathrm{U}$ versus $+\mathrm{C}+\mathrm{U}$ & & 2.23 & & 2.85 & & 2.28 & \\
\hline$-\mathrm{C}-\mathrm{U}$ versus $+\mathrm{C}-\mathrm{U}$ & & 1.32 & & 1.76 & & 2.13 & \\
\hline$+\mathrm{C}+\mathrm{U}$ versus $+\mathrm{C}-\mathrm{U}$ & & 1.74 & & 1.73 & & 1.29 & \\
\hline
\end{tabular}

The other categories of algae included in multivariate analyses such as articulated corallines, and coarsely branched and laminar thallus forms were poorly represented. Covers were too small for analysis (largest values never exceeding $5 \%$ ).

Filamentous algae were scarce in control patches, but their percentage cover increased following the removal of sea urchins and, to a lesser extent, after the removal of encrusting corallines (Fig. 3A). The effects of the removal of urchins on the abundance of filamentous algae were consistent across sites (Table 2). Conversely, there was no significant effect of the manipulation of encrusting corallines, although this enabled filamentous algae to colonise patches despite the presence of urchins. The abundance of filamentous algae was consistent across sites, but variable among patches (Fig. 3A, Table 2).

Acetabularia acetabulum was very scarce in control patches at the study sites. The removal of either urchins or encrusting corallines positively affected the percentage cover of this alga, consistently across sites (Fig. 3B, Table 2). Encrusting corallines appeared to be very effective in controlling the abundance of $A$. acetabulum, the cover of which remained small whenever encrusting corallines were left untouched. Although the analysis did not show a significant interaction, the removal of urchins led to an increase in the abundance of this alga only in the absence of encrusting corallines. Finally, the abundance of this alga varied from patch to patch (Table 2).

Padina pavonica was affected by the manipulation of sea urchins as well as by the manipulation of encrusting corallines, although their effects were in opposite directions (Fig. 3C, Table 2). The removal of encrusting corallines had negative effects on $P$. pavonica and its cover was very small when they were removed; the positive effects of the removal of sea urchins were more evident when the crusts were not manipulated. As reported for A. acetabulum, the effects of urchins and corallines were not interactive (Table 2). The abundance of $P$. pavonica was consistent among sites, but varied between patches.

Vermetus spp. was the only sessile invertebrate colonising experimental plots. Manipulative conditions did not affect its abundance, which was generally very small and varied between patches (analysis of $\ln (x+1)$ transformed data, $C=0.174, \mathrm{p}>0.05$, Patch $(\mathrm{S} \times \mathrm{C} \times \mathrm{U})$ : $\left.F_{12,72}=1.96^{*}, \mathrm{MS}=0.364\right)$.

\section{DISCUSSION}

The results suggest that the occurrence of areas dominated by encrusting corallines on shallow subtidal reefs in the northwest Mediterranean is not simply the result of grazing by sea urchins on turf-forming species. The removal of encrusting corallines also affected the abundance of dominant algal species and determined the development of an algal assemblage resembling those occurring within stands of algal turfs.

The effects of the manipulation were generally consistent among sites (tens of metres apart), but they were variable among patches and among replicates. This variability was particularly evident in the $-\mathrm{C}+\mathrm{U}$ and $-\mathrm{C}-\mathrm{U}$ treatments.

At the same location, Benedetti-Cecchi et al. (1998) and Bulleri et al. (1999) reported that the effects of grazing by Paracentrotus lividus and Arbacia lixula on 

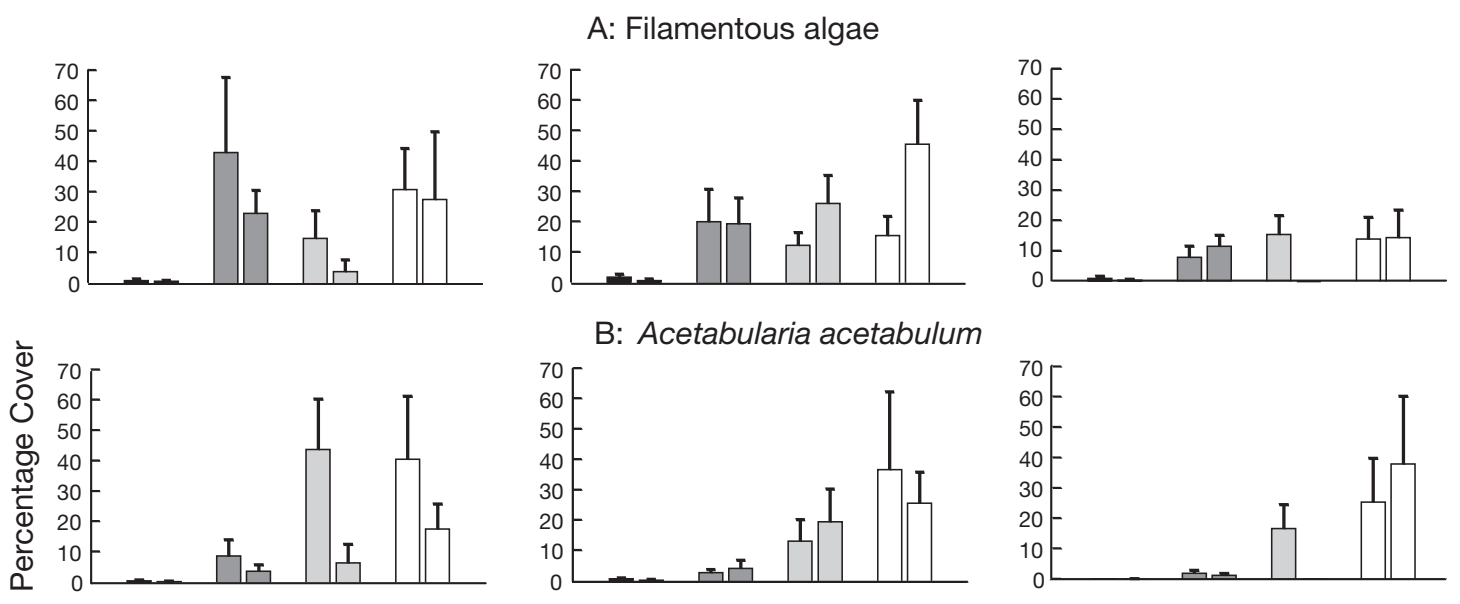

B: Acetabularia acetabulum
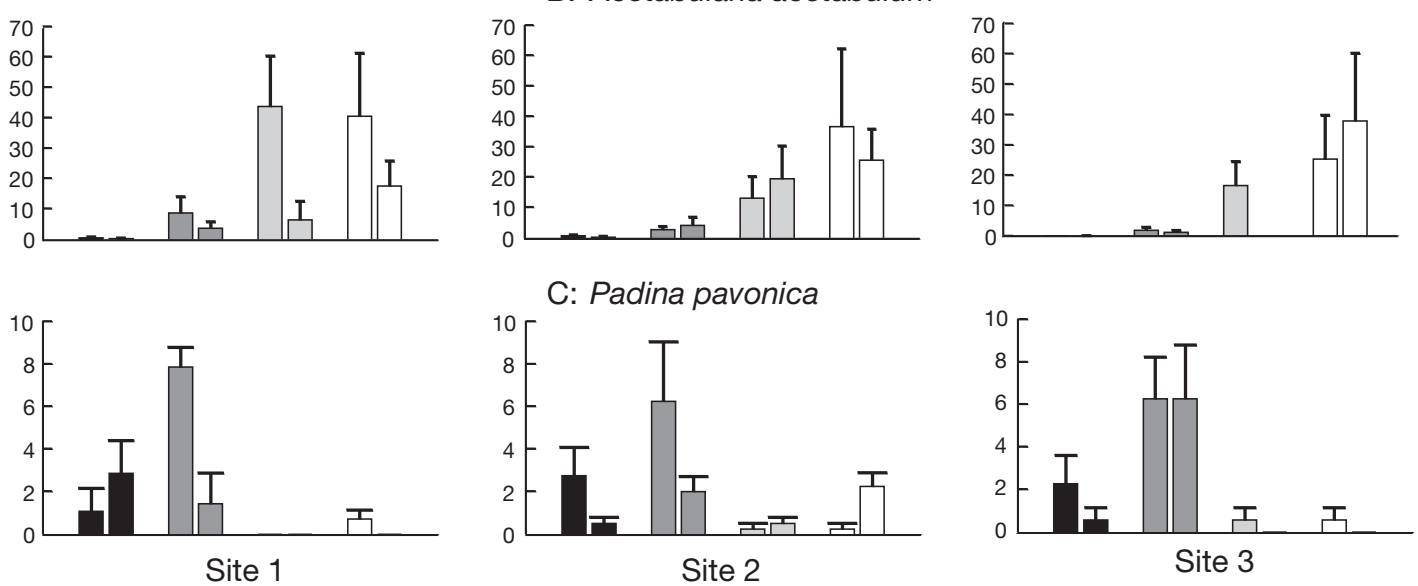

Fig. 3. Effects of the removal of sea urchins and encrusting corallines on (A) filamentous algae, (B) Acetabularia acetabulum and (C) Padina pavonica, separately for each site. Data are percentage cover values averaged across 4 replicate quadrats in each patch. Black bars $=+\mathrm{C}+\mathrm{U}$; dark grey bars $=+\mathrm{C}-\mathrm{U}$; light grey bars $=-\mathrm{C}+\mathrm{U}$; hollow bars $=-\mathrm{C}-\mathrm{U}$

the algal assemblages were variable at the scales of metres and tens of centimetres. Furthermore, Benedetti-Cecchi \& Cinelli (1995) showed that the effects of grazing by $P$. lividus on algal assemblage were limited to the space (a few centimetres) in front of crevices. On the other hand, the variability within and between patches was larger where encrusting corallines were removed relative to where they were left untouched, irrespective of the presence or absence of sea urchins. This suggests that the presence of encrusting corallines, rather than grazing by herbivores, may be the main source of this variability. The extent to which encrusting corallines re-colonised space, likely through encroachment from the margins of the quadrats, which strongly varied (from 0 to $96 \%$ at the end of the experiment), may have affected the

Table 2. Analysis of the effects of site, corallines, urchins and patch on the mean percentage cover of filamentous algae, Acetabularia acetabulum and Padina pavonica

\begin{tabular}{|c|c|c|c|c|c|c|c|}
\hline \multirow[t]{2}{*}{ Source of variation } & \multirow[t]{2}{*}{$\mathrm{df}$} & \multicolumn{2}{|c|}{ Filamentous algae } & \multicolumn{2}{|c|}{ A. acetabulum } & \multicolumn{2}{|c|}{ P. pavonica } \\
\hline & & MS & $F$ & MS & F & MS & F \\
\hline Site $=\mathrm{S}$ & 2 & 8.189 & $2.53 \mathrm{~ns}$ & 3.916 & $1.54 \mathrm{~ns}$ & 0.906 & $1.17 \mathrm{~ns}$ \\
\hline$+\backslash-$ Corallines $=\mathrm{C}$ & 1 & 8.139 & $4.69 \mathrm{~ns}$ & 64.858 & $308.34^{* * *}$ & 11.229 & $125.78^{* *}$ \\
\hline$+\backslash-$ Urchins $=\mathrm{U}$ & 1 & $28.975^{\mathrm{a}}$ & $9.33^{*}$ & 13.929 & $946.74^{* * *}$ & 4.306 & $67.02^{*}$ \\
\hline $\mathrm{S} \times \mathrm{C}$ & 2 & 1.734 & $0.54 \mathrm{~ns}$ & 0.050 & $0.02 \mathrm{~ns}$ & 0.089 & $0.12 \mathrm{~ns}$ \\
\hline $\mathrm{S} \times \mathrm{U}$ & 2 & 2.985 & $0.92 \mathrm{~ns}$ & 0.005 & $0.00 \mathrm{~ns}$ & 0.064 & $0.08 \mathrm{~ns}$ \\
\hline $\mathrm{C} \times \mathrm{U}$ & 1 & 5.323 & $6.81 \mathrm{~ns}$ & 0.019 & $0.01 \mathrm{~ns}$ & 1.338 & $7.16 \mathrm{~ns}$ \\
\hline $\mathrm{S} \times \mathrm{C} \times \mathrm{U}$ & 2 & 0.781 & $0.24 \mathrm{~ns}$ & 2.504 & $0.99 \mathrm{~ns}$ & 0.187 & $0.24 \mathrm{~ns}$ \\
\hline Patch $(\mathrm{S} \times \mathrm{C} \times \mathrm{U})$ & 12 & 3.234 & $2.68^{* *}$ & 2.535 & $1.99^{*}$ & 0.775 & $3.07^{* *}$ \\
\hline Residual & 72 & 1.208 & 1.273 & 0.252 & & & \\
\hline Cochran's test & & \multirow{2}{*}{\multicolumn{2}{|c|}{$\begin{array}{c}C=0.174, \mathrm{p}>0.05 \\
\ln (x+1)\end{array}$}} & \multirow{2}{*}{\multicolumn{2}{|c|}{$\begin{array}{c}C=0.144, \mathrm{p}>0.05 \\
\ln (x+1)\end{array}$}} & \multirow{2}{*}{\multicolumn{2}{|c|}{$\begin{array}{c}C=0.144, \mathrm{p}>0.05 \\
\ln (x+1)\end{array}$}} \\
\hline Transformation & & & & & & & \\
\hline
\end{tabular}


rates of colonisation by turfing algae, producing such high variability. This explanation would stress the importance of the active role played by encrusting corallines in maintaining space free of erect algal species. Alternatively, this variability may reflect the variability in the recruitment of turfing algae at small spatial scale.

An approach to the interpretation of the a posteriori comparisons, based on the concept of a gradient of differences among treatments (step-wise model), would indicate that assemblages which developed within turf-forming algal stands were different from those occurring where encrusting corallines were left untouched, but not from those where the latter were removed, irrespective of the manipulation of sea urchins. This would be in partial contrast to our predictions, given that the removal of only encrusting corallines should have been sufficient for the development of an assemblage similar to that occurring within surrounding stands of turfing algae.The effects of the removal of sea urchins on the most abundant erect algal species were generally positive, while those of the removal of encrusting corallines were positive on some algal species and negative on others.

As previously documented at the study site (Benedetti-Cecchi et al. 1998, Bulleri et al. 1999), filamentous algae positively responded to the removal of sea urchins. Following the removal of encrusting corallines, their percentage cover underwent a considerable increase, even when sea urchins were present, suggesting that the crusts also influence the re-colonisation of turfforming species. It is likely that the low power of the test and the large variability between patches prevented the analysis from detecting significant effects of the manipulation of encrusting corallines on filamentous algae.

The percentage cover of Acetabularia acetabulum drastically increased when encrusting corallines and sea urchins were removed. The presence of encrusting corallines was effective in deterring the colonisation of A. acetabulum, overwhelming the positive effects of removing sea urchins and suggesting the occurrence of interactive effects, which, however, were not revealed by the analysis. Conversely, the abundance of Padina pavonica was greater where encrusting corallines were left untouched and sea urchins were removed. Encrusting corallines could have positively affected the colonisation of $P$. pavonica, or, alternatively, their removal may have enabled $A$. acetabulum to out-compete this alga. Positive effects of encrusting corallines on the recruitment and survival of invertebrates have been reported (Steneck 1982, Morse \& Morse 1984, Sheperd \& Turner 1985, Day \& Branch 2000), but there is no evidence for such positive effects on algal species. This would support the proposition that patterns of abundance of $P$. pavonica could be the outcome of interspecific competition, suggesting that the indirect negative effects of the removal of encrusting corallines were stronger than direct positive ones.

Surprisingly, the colonisation of other locally common erect algal species, such as articulated corallines, foliose and coarsely branched algae, was always very sparse, never reaching values worth analysing. We speculate that making space available for colonisers at the time of recruitment of Acetabularia acetabulum could have led to the unpredicted poor development of these erect algal species. On the other hand, some of these algae have been reported to be reproductive all year round and, particularly for A. acetabulum and Padina pavonica, from late-summer to early-autumn (Airoldi 2000), likely minimising any potential bias of the time of start of the experiment.

It has generally been concluded that grazing by sea urchins is the main factor generating encrusting coralline-dominated areas and that their effects can be variable in space and through time, according to a wide set of physical and biotic factors (Elner \& Vadas 1990, Andrew 1993, Hagen 1995, Benedetti-Cecchi et al. 1998, Bulleri et al. 1999). As a consequence, it has been proposed that, during periods of limited foraging activity by sea urchins, the ability of encrusting corallines to prevent the re-colonisation of erect algae could play a primary role in determining the dynamics of contrasting algal assemblages (Breitburg 1984). As reported by some authors (Masaki et al. 1981, 1984, Breitburg 1984, Littler \& Littler 1984, Johnson \& Mann 1986), sloughing and shedding of epithallial cells from the surface of encrusting corallines can be an effective mechanism for reducing the establishment of fouling organisms.

Indeed, this study showed that the importance of the effects of encrusting corallines in preventing the recovery of turf-forming algal species was not limited to areas deprived of grazers. In general, the effects of encrusting corallines and sea urchins on the re-colonisation of turf-forming assemblages operated in the same directions, but, in contrast to our prediction, the former were not weaker than the latter. The effects of encrusting corallines were not hidden by the presence of herbivores, but rather their removal was necessary to trigger the transition from the barren state towards the turfing state. In light of the active role played by encrusting corallines in maintaining space, evaluation of the effects of physical disturbance is critical in determining the spatial and temporal dynamics of the 2 alternative algal assemblages. The intervention of severe events of disturbance, like storms, removing discrete patches of encrusting corallines and providing bare substratum to be colonised (Bulleri pers. obs.), could trigger, or speed up, the process of recovery by 
turfing assemblages. Several studies have shown that the removal of grazers caused the change from a barren state to a more productive state dominated by algal canopies within 1-2 yr (Chapman 1981, Andrew \& Choat 1982, Dayton 1985, Johnson \& Mann 1988). Conversely, Benedetti-Cecchi et al. (1998), in a study on the northwest coast of Italy, reported that the partial and total removal of sea urchins from barren patches did not result in any significant change in their extent after $18 \mathrm{mo}$, suggesting that the persistence of this kind of algal assemblage could not be explained only in terms of grazing. As argued by the same authors (Benedetti-Cecchi et al. 1998), different life-history traits between kelps and the turf-forming species occurring in the Mediterranean Sea could account for the difference, increasing the difficulty of assessing the generality of the experimental results. This study, however, suggests the need for taking into account the role played by encrusting corallines in maintaining alternative habitats on shallow subtidal reefs, thus avoiding the overestimation of the effects of grazing by sea urchins.

Acknowledgements. We sincerely thank F. Rindi for help in the field, A. H. Dye, J. Grayson, A. J. Underwood and 3 anonymous reviewers for helpful comments on the manuscript. M. J. Anderson kindly provided advice on multivariate analyses. Discussion with L. Benedetti-Cecchi, during all the stages of this study, was much appreciated. M. Pizza (Spazio Sub) kindly, and for free, supplied part of the SCUBA gear. This manuscript was written while F.B. was supported by an IPRS/IPA scholarship from the University of Sydney, at the Centre for Research on Ecological Impacts of Coastal Cities.

\section{LITERATURE CITED}

Airoldi L (2000) Responses of algae with different life histories to temporal and spatial variability of disturbance in subtidal reefs. Mar Ecol Prog Ser 195:81-92

Anderson MJ (2001) A new method for non-parametric multivariate analysis of variance. Aust Ecol 26:32-46

Andrew NL (1993) Spatial heterogeneity, sea urchins grazing, and habitat structure on reefs in temperate Australia. Ecology 74:292-302

Andrew NL, Choat JH (1982) The influence of predation and conspecifics adults on the survivorship of juvenile Evechinus cloroticus (Echinoidea: Echinometridae). Oecologia 54:80-87

Andrew NL, Underwood AJ (1993) Density-dependent foraging in the sea urchin Centrostephanus rodgersii on shallow subtidal reefs in New South Wales, Australia. Mar Ecol Prog Ser 99:89-98

Benedetti-Cecchi L, Cinelli F (1995) Habitat heterogeneity, sea urchins grazing and the distribution of algae in littoral rock pools in the west coast of Italy (western Mediterranean). Mar Ecol Prog Ser 126:203-212

Benedetti-Cecchi L, Bulleri F, Cinelli F (1998) Density-dependent foraging of sea urchins in shallow subtidal reefs on the west coast of Italy (western Mediterranean). Mar Ecol Prog Ser 163:203-211
Bertness MD, Yund PO, Brown AF (1983) Snail grazing and the abundance of algal crusts on a sheltered New England rocky beach. J Exp Mar Biol Ecol 71:147-164

Boudoresque CF (1987) Colloque international sur Paracentrotus lividus et les oursins comestibles. GIS Posidonie Publ, Marseilles

Branch GM (1975) Mechanisms reducing intraspecific competition in Patella spp.: migration, differentiation and territorial behaviour. J Anim Ecol 44:575-600

Bray JR, Curtis JT (1957) An ordination of the upland forest communities of southern Wisconsin. Ecol Monogr 27: 325-349

Breitburg DL (1984) Residual effects of grazing: inhibition of competitor recruitment by encrusting coralline algae. Ecology 65(4):1136-1143

Bulleri F, Benedetti-Cecchi L, Cinelli F (1999) Grazing by the sea urchins Arbacia lixula L. and Paracentrotus lividus Lam. in the northwest Mediterranean. J Exp Mar Biol Ecol 241:81-95

Camus PA (1994) Recruitment of the intertidal kelp Lessonia nigrescens Bory in northern Chile: successional constraints and opportunities. J Exp Mar Biol Ecol 184:171-181

Carpenter RC (1984) Predator and population density control of homing behaviour in the Caribbean echinoid Diadema antillarum. Mar Biol 82:101-108

Chapman ARO (1981) Stability of urchin-dominated barren grounds following destructive grazing of kelp in St. Margarets Bay, eastern Canada. Mar Biol 62:307-311

Chapman MG, Underwood AJ (1992) Foraging behaviour of marine benthic grazers. In: John DM, Hawkins SJ, Price JH (eds) Plant-animal interactions in the marine benthos, Spec Vol 46. Systematics Association, Clarendon Press, Oxford, p 289-317

Cowen RK, Agegian CR, Foster MS (1982) The maintenance of community structure in a central California giant kelp forest. J Exp Mar Biol Ecol 64:189-201

Day E, Branch GM (2000) Relationships between recruits of abalone Haliotis midae, encrusting corallines and the sea urchin Parechinus angulosus. S Afr J Mar Sci 22:137-144

Dayton PK (1985) The structure and regulation of some south American kelp communities. Ecol Monogr 45:137-159

Dethier MN (1994) The ecology of intertidal algal crusts: variation within a functional group. J Exp Mar Biol Ecol 177: $37-71$

Dethier MN, Graham ES, Cohen S, Tear LM (1993) Visual versus random-point percent cover estimations: 'objective' is not always better. Mar Ecol Prog Ser 110:9-18

Elner RW, Vadas RL (1990) Inference in ecology - the sea urchin phenomenon in the northwestern Atlantic. Am Nat 136:108-125

Fanelli G, Piraino S, Belmonte G, Geraci S, Boero F (1994) Human predation along Apulian rocky coast (SE Italy): desertification caused by Litophaga litophaga (Mollusca) fisheries. Mar Ecol Prog Ser 110:1-8

Fletcher WJ (1987) Interactions among subtidal Australian sea urchins, gastropods and algae: effects of experimental removals. Ecol Monogr 57:89-109

Hagen NT (1995) Recurrent destructive grazing of successionally immature kelp forests by green sea urchins in Vestfjorden, northern Norway. Mar Ecol Prog Ser 123: 95-106

Hawkins SJ, Hartnoll RG (1983) Grazing of intertidal algae by marine invertebrates. Oceanogr Mar Biol Annu Rev 21: 195-282

Himmelmann JH, Cardinal A, Bourget E (1983) Community development following removal of urchins, Strongylocentrotus droebachensis, from the rocky subtidal zone of 
the St. Lawrence estuary, eastern Canada. Oecologia 59: $27-39$

Johnson CR, Mann KH (1986) The crustose coralline alga, Phymatolithon Foslie, inhibits the overgrowth of seaweeds without relying on herbivores. J Exp Mar Biol 96:127-146

Johnson CR, Mann KH (1988) Diversity, patterns of adaptation, and stability of Nova Scotian kelp beds. Ecol Monogr 58:129-154

Kempf M (1962) Recherches d'écologie comparée sur Paracentrotus lividus (Lmk.) et Arbacia lixula (L.). Rec Trav Stn Mar Endoume Fac Sci Mars 25:47-116

Kitting CL (1980) Herbivore-plant interactions of individual limpets maintaining a mixed diet of intertidal algae. Ecol Monogr 50:527-550

Lawrence JM (1975) On the relationships between marine plants and sea urchins. Oceanogr Mar Biol Annu Rev 13: 213-286

Leinaas HP, Christie H (1996) Effects of removing sea urchins (Strongylocentrotus droebachiensis): stability of the barren state and succession of kelp forest recovery in the east Atlantic. Oecologia 105:524-536

Levings SC, Garrity SD (1983) Diel and tidal movements in two co-occurring neritid snails: differences in grazing patterns on a tropical rocky shore. J Exp Mar Biol Ecol 67: 261-278

Littler MM, Littler DS (1980) The evolution of thallus form and survival in benthic marine macroalgae: field and laboratory tests of a functional form model. Am Nat 116:25-44

Littler MM, Littler DS (1984) Models of tropical reefs biogenesis: the contributions of algae. Prog Phycol Res 3:323-364

Lively CM (1986) Predator-induced shell dimorphism in the acorn barnacle Chthamalus anisopoma. Evolution 40: $232-242$

Masaki T, Fujita D, Akioka H (1981) Observation on the spore germination of Laminaria japonica on Litophyllum yessoense (Rhodophyta: Corallinacee) in culture. Bull Fac Fish Hokkaido Univ 32:349-356

Masaki T, Fujita D, Hagen NT (1984) The surface ultrastructure and epithallium shedding of crustose coralline algae in an 'Isoyake' area of southwestern Hokkaido, Japan. Hydrobiologia 116-117:218-223

Menge BA (1978) Predation intensity in a rocky intertidal community: relation between predator foraging and environmental harshness. Oecologia 34:1-16

Morse ANC, Morse DE (1984) Recruitment and metamorphosis of Haliotis larvae induced by molecules uniquely available at the surfaces of crustose red algae. J Exp Mar Biol Ecol 75:191-215

Nelson BV, Vance RR (1979) Diel foraging patterns of the sea urchins Centrostephanus coronatus as a predator avoidance strategy. Mar Biol 51:251-258

Odgen JC, Brown RA, Salesky N (1973) Grazing by the echinoid Diadema antillarum Philippi: formation of halos around West Indian patch reefs. Science 182:715-717

Paine RT (1980) Food webs: linkage, interaction strength and community infrastructure. The Third Tansley lecture. J Anim Ecol 49:667-685

Regis MB (1978) Croissance de deux echinoids du Golfe de Marseille (Paracentrotus lividus (Lmk.) et Arbacia lixula L.). Aspects écologique de la microstructure du squelette

Editorial responsibility: Roger Hughes (Contributing Editor), Bangor, Wales, UK et de l'évolution des indices physiologiques. Thése Sci. Nat., Univ. St. Jérome, Aix-Marseille I, France

Sala E, Zabala M (1996) Fish predation and the structure of the sea urchin Paracentrotus lividus populations in NW Mediterranean. Mar Ecol Prog Ser 140:71-81

Scheibling RE (1986) Increased macroalgal abundance following mass mortalities of sea urchins (Strongylocentrotus droebachiensis) along the Atlantic coast of Nova Scotia. Oecologia 68:186-198

Scheibling RE, Hamm J (1991) Interactions between sea urchins (Strongylocentrotus droebachiensis) and their predators in field and laboratory experiments. Mar Biol 110: 105-116

Sebens KP (1983) Settlement and metamorphosis of a temperate soft-coral larva (Alcyonium siderium Verril): induction by crustose algae. Biol Bull (Woods Mole) 165:286-304

Sheperd SA, Turner JA (1985) Studies on southern Australian abalone (Genus Haliotis): habitat preference, abundance and predators of juveniles. J Exp Mar Biol Ecol 93: 285-298

Sousa WP, Schroeter SC, Gaines SD (1981) Latitudinal variation in intertidal algal community structure: the influence of grazing and vegetative propagation. Oecologia 48: 297-307

Steneck RS (1982) A limpet-coralline alga association: adaptations and defences between a selective herbivore and its prey. Ecology 63:507-522

Steneck RS (1986) The ecology of coralline algal crusts: convergent patterns and adaptive strategies. Annu Rev Ecol Syst 17:273-303

Underwood AJ (1997) Experiments in ecology: their local design and interpretation using analysis of variance. Cambridge University Press, Cambridge

Underwood AJ (1999) Physical disturbances and their direct effect on an indirect effect: responses of an intertidal assemblage to a severe storm. J Exp Mar Biol Ecol 232: $125-140$

Valentine JF, Heck KL (1991) The role of sea urchin grazing in regulating subtropical seagrass meadows: evidence from field manipulations in the Northern Gulf of Mexico. J Exp Mar Biol Ecol 154:215-230

Vance RR, Schmitt RJ (1979) The effect of predator-avoidance behaviour of the sea urchin Centrostephanus coranatus, on the breadth of its diet. Oecologia 44:21-25

Verlaque M (1984) Biologie des juvéniles de l'oursin herbivore Paracentrotus lividus (Lamark): sélectivité du brutage et impact de l'espéce sur les communautés algales de substrat rocheux en Corse (Méditerranée, France). Bot Mar 27:401-424

Verlaque M, Nedelec H (1983) Biologie de Paracentrotus lividus (Lamark) sur substratum rocheux en Corse (Méditerranée, France): alimentation des adultes. Vieu Milieu 33:191-202

Williams GA, Davies MS, Nagarkar S (2000) Primary succession on a seasonal tropical rocky shore: the relative roles of spatial heterogeneity and herbivory. Mar Ecol Prog Ser 203:81-94

Witman JD (1987) Subtidal coexistence: storms, grazing, mutualism, and the zonation of kelps and mussels. Ecol Monogr 57:167-187

Submitted: March 7, 2002; Accepted: June 11, 2002 Proofs received from author(s): October 18, 2002 